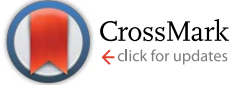

Cite this: RSC Adv., 2017, 7, 17620

Received 29th January 2017

Accepted 14th March 2017

DOI: $10.1039 / c 7 r a 01259 d$

rsc.li/rsc-advances

\title{
Microtubular solid oxide fuel cells fabricated by gel-casting: the role of supporting microstructure on the mechanical properties
}

\begin{abstract}
M. Morales ${ }^{\star a}$ and M. A. Laguna-Bercero ${ }^{b}$
Different cell configurations of anode-supported microtubular solid oxide fuel cells (mT-SOFCs) using samaria-doped ceria (SDC) as the electrolyte were fabricated. Several cells were processed varying the porosity and wall thickness (outer diameter) of $\mathrm{NiO}-\mathrm{SDC}$ tubular supports. Suitable aqueous slurry formulations of $\mathrm{NiO}-\mathrm{SDC}$ for gel-casting were prepared using agarose, as a gelling agent, and sucrose, as a pore former. The subsequent $\mathrm{NiO}-\mathrm{SDC}$ anode functional layer (AFL), the SDC electrolyte and the $\mathrm{La}_{0.6} \mathrm{Sr}_{0.4} \mathrm{CO}_{0.2} \mathrm{Fe}_{0.8} \mathrm{O}_{3-\delta}-\mathrm{SDC}$ cathode were deposited by spray-coating. Afterwards, the electrochemical performance of different single cells was tested under humidified hydrogen as the fuel and air as the oxidant. The mechanical strength of the supporting tubes at different processing stages (green, pre-/ post-sintering, post-reduction, post-redox cycle conditions) were also determined to study the macromechanical failure behaviour of the cells. In addition, the mechanical strength of half-cells with different porosity, sintering temperature and wall thickness in the tubular supports was also determined. For this purpose, the modulus of rupture was measured by a three point bending test. This study shows that the electrochemical properties and mechanical strength are feasible for further development of anodesupported mT-SOFCs fabricated by gel-casting.
\end{abstract}

\section{Introduction}

Solid oxide fuel cells (SOFCs) are electrochemical energy conversion devices applicable from portable systems of a few watts up to megawatt-sized power plants with high efficiency and low emissions of pollution. ${ }^{\mathbf{1} 2}$ SOFCs can also be used for portable applications, as Auxiliary Power Units (APUs), in the transport sector or as small power units for personnel, submarines, airplanes, etc. Tubular SOFC designs have been demonstrated to be effective for portable devices, due to their high thermal shock resistance, less stringent sealing requirements, and a low thermal stress caused by rapid heating up to the operating temperature. ${ }^{3,4}$ By decreasing the tubular cell diameter to a few millimetres or sub-millimetres, such as mT-SOFCs, it is possible to improve the mechanical stability, thermo-cycling resistance, volumetric power density, and to reduce the times of start-up and shut-down. ${ }^{5-10}$ In addition, enhancing the performance at low operation temperatures also allows using costeffective materials for interconnects and balance of plant. ${ }^{11}$ For this purpose, both decrease of the electrolyte thickness to reduce the ohmic resistance losses and using electrolytes based on gadolinium doped ceria (GDC), samarium doped ceria (SDC), or

${ }^{a}$ IREC, Catalonia Institute for Energy Research, Dept of Advanced Materials for Energy Applications, Jardins de les Dones de Negre 1, Planta 2, 08930, Sant Adrià del Besós, Barcelona, Spain.E-mail: mmorales@irec.cat; mmoralescomas@yahoo.es

${ }^{b}$ Instituto de Ciencia de Materiales de Aragón, ICMA, CSIC - Universidad de Zaragoza, Pedro Cerbuna 12, 50009 Zaragoza, Spain strontium and magnesium doped $\mathrm{LaGaO}_{3}$ perovskite (LSGM), which present high ionic conductivity at intermediate temperatures, are good approaches. ${ }^{12-15}$

For anode-supported tubular cells, volumetric power density depends on the inverse of cell diameter; so the narrowest diameter presents the best electrochemical performance. ${ }^{16}$ In addition, the performance is also strongly affected by the wall thickness and the porosity of anode support. The best mT-SOFC performance reported in the open literature was achieved by Suzuki et al. ${ }^{17}$ which achieved a power density higher than $1.1 \mathrm{~W} \mathrm{~cm}^{-2}$ (at $600{ }^{\circ} \mathrm{C}$ ) with $1.9 \mathrm{~mm}$ diameter and a porosity of $54 \%$ (before reduction). This represents a good balance between porosity to aid gas flow and continuity of material to help the electrical conductivity. The effect of pore former amounts and the type of material used as a pore former have been also investigated by several researchers. ${ }^{18,19}$ In general, tubular supports with high values in porosity are weaker mechanically. For instance, Roy et al. ${ }^{19}$ quantified this weakening for several volume percentages of pore former $(40 \%, 50 \%$ and $60 \%$ ), thus observing a drop of $26 \%$ in average burst strength for each $10 \%$ volumetric increment of pore former. The average burst strength was $11.7 \pm 7.5 \mathrm{MPa}$ for the tested tubes with $60 \%$ poreformer by volume. It may be sufficient in many cases. However, this weakening effect due to the added porosity must be considered when high mechanical resistances in cells are required. Therefore, the design of mT-SOFCs should be balanced between their electrical and mechanical properties. In addition, the manufacturing of these devices should not be only focussed on 
electrochemical performance, but also on mechanical properties. The cells should require a minimum strength to allow their handling during single-cell manufacturing and their assembling into fuel-cell stack. They must also survive to thermal cycling under operation conditions. The failure of a cell in a stack will decrease the stack efficiency, as well as shorten considerably its lifetime. Therefore, the mechanical strength of the different components of the mT-SOFCs is critical for their future implementation. Despite these mechanical requirements, the specific study of the mechanical properties of mT-SOFCs has not received much attention. Up to date, only several studies about mechanical and thermal characterization of tubular anode-supports ${ }^{18,20-24}$ and electrolyte-supports ${ }^{25}$ fabricated by extrusion technique have been reported. The cells were characterized mechanically using macroscopic techniques, such as three- or four-point bending, burst testing and c-ring testing.

Owing to the important electrochemical and mechanical requirements of tubular cells, the manufacturing of the support is probably the most important part in microtubular SOFC research. It presents several technical difficulties, particularly in terms of a relatively high investment in equipment and a long time for the adjustment of processing parameters. Typical fabrication procedures for the tubular support include cold isostatic pressing, ${ }^{26,27}$ slip-casting, ${ }^{28,29}$ powder extrusion moulding, ${ }^{30,31}$ electrophoretic deposition $^{32}$ and co-extrusion ${ }^{33}$ amongst others. Alternatively, aqueous gel-casting is a wet-forming technique that allows to prepare dense and porous ceramics, with high quality and complex geometry, in short forming times, and low-cost equipment. $^{34-37}$ Morales et al. ${ }^{38-40}$ reported a new methodology combining the agarose gel-casting and spray-coating techniques that are easily industrially scalable for processing of the anodesupported tubular cells based on NiO-Sm ${ }_{0.2} \mathrm{Ce}_{0.8} \mathrm{O}_{1.9} /$ $\mathrm{Sm}_{0.2} \mathrm{Ce}_{0.8} \mathrm{O}_{1.9} / \mathrm{La}_{0.6} \mathrm{Sr}_{0.4} \mathrm{Co}_{0.2} \mathrm{Fe}_{0.8} \mathrm{O}_{3-d}-\mathrm{Sm}_{0.2} \mathrm{Ce}_{0.8} \mathrm{O}_{1.9} \quad$ (Ni-SDC/ SDC/LSCF-SDC). Tubular supports were shaped by a gel-casting method based on a new and simple forming technique, which operates as a syringe. Electrochemical performance of mT-SOFC cells fabricated by agarose gel-casting was optimized. The cell with a support of $2.4 \mathrm{~mm}$ outer diameter, $380 \mu \mathrm{m}$ wall thickness, and using $10 \mathrm{wt} \%$ sucrose as a pore former, achieved a power density of $0.4 \mathrm{~W} \mathrm{~cm}^{-2}$ at $650{ }^{\circ} \mathrm{C}$. In the present work, special attention will be focused on the effect of the support on the mechanical properties for anode-supported microtubular SOFCs fabricated by gel-casting. For this purpose, several NiO-SDC tubular supports were manufactured varying different processing parameters: porosity, sintering temperature and wall thickness (outer diameter). The relationships between manufacturing parameters and electrochemical and mechanical properties will be discussed. In addition, the mechanical strength of the supporting tubes at different processing stages will be analysed to study the macro-mechanical failure behaviour of the cells.

\section{Experimental procedure}

\subsection{Cell manufacturing}

The mT-SOFCs were fabricated using the process developed in our previous studies. ${ }^{38,39}$ Compositions and dimensions of the cells were initially selected based on preliminary electrochemical results. ${ }^{40}$ Samarium-doped ceria, nickel oxide-samarium doped ceria ( $60: 40$ and $50: 50 \mathrm{wt} \%$ ), and lanthanum strontium cobaltite powders, with a nominal composition of $\mathrm{Sm}_{0.2} \mathrm{Ce}_{0.8} \mathrm{O}_{1.9}$ (SDC), $\mathrm{NiO}-\mathrm{Sm}_{0.2} \mathrm{Ce}_{0.8} \mathrm{O}_{1.9}$ (NiO-SDC) and $\mathrm{La}_{0.6} \mathrm{Sr}_{0.4} \mathrm{Co}_{0.2} \mathrm{Fe}_{0.8} \mathrm{O}_{3-\delta}$ (LSCF) respectively, were synthesized by polyacrylamide gel combustion as described elsewhere. ${ }^{41,42}$ All these powders were characterized by BET specific surface and XRD in order to confirm their quality. The composition of the microtubular SOFCs was selected as follows: NiO-SDC (60: $40 \mathrm{wt} \%)$ as the anode tubular support, NiO-SDC $(50: 50 \mathrm{wt} \%)$ as the anode functional layer (AFL), SDC as the electrolyte and LSCF-SDC $(70: 30 \mathrm{wt} \%)$ as the cathode. The reference tubular support of cells, used as a baseline for variation processing parameters, was fabricated with a formulation consisted of $1.0 \mathrm{wt} \%$ dispersant/solid loading (DOLAPIX GmbH \& Co), $34 \mathrm{wt} \% \mathrm{NiO}-\mathrm{SDC}$ solid loading/water, $10 \mathrm{wt} \%$ sucrose/solid loading as a pore former, and $0.90 \mathrm{wt} \%$ agarose (Lab. Conda)/ suspension (in vol.) as a gelling agent. In order to obtain a homogeneous slurry, the agarose suspension was firstly activated by heating around $80-90{ }^{\circ} \mathrm{C}$, and then kept above $40{ }^{\circ} \mathrm{C}$ until casting. Tubes were extruded by gel-casting using a steel punch $(\varnothing=3 \mathrm{~mm})$ with an in-house-designed aluminium die $(\varnothing=6 \mathrm{~mm}$, and length $=250 \mathrm{~mm}$ ). The resulting green tubes were finally dried in air for $48 \mathrm{~h}$, and cut to a length of 100-120 mm. Afterwards, an anode functional layer ( $50: 50 \mathrm{wt} \% \mathrm{NiO}-\mathrm{SDC}$ and $15 \mu \mathrm{m}$ thickness) was deposited by colloidal spray-coating onto the tubular substrates, and then pre-sintered at $1100{ }^{\circ} \mathrm{C}$. Subsequently, the SDC electrolyte layer (15 $\mu \mathrm{m}$ thickness) was deposited by colloidal spray-coating, which was also made by mixing commercial SDC with cobalt oxide (2.0 wt\%) used as a sintering aid. Then, both anode and electrolyte were co-sintered at $1450{ }^{\circ} \mathrm{C}$ for $5 \mathrm{~h}$. After co-sintering, the $70: 30 \mathrm{wt} \%$ LSCF-SDC cathode was sprayed onto the halfcell and sintered at $1050{ }^{\circ} \mathrm{C}$ for $2 \mathrm{~h}$ in air. Final cell dimensions are: $2.4 \mathrm{~mm}$ outer diameter, $380 \mu \mathrm{m}$ wall thickness, $80-100 \mathrm{~mm}$ in length, and a cathode active area of $60-100 \mathrm{~mm}^{2}$, in order to keep the cells in the isothermal zone of the furnace. Microstructures of the cell components were analyzed by field emission scanning electron microscope (Merlin FE-SEM, Carl Zeiss). The porosity amount and the pore size distribution of the supports, after reduction of $\mathrm{NiO}$ to $\mathrm{Ni}$, were determined by $\mathrm{Hg}$-porosimetry (Quantachrome Poremaster porosimeter). The relative density of SDC electrolyte layer was determined by image analysis using DigitalMicrograph (TM) 365 (Gatan Inc., USA) software. For this purpose, three different images for each sample taken with identical magnification $(\times 5000)$ were analyzed. The volume fraction of pore phase was calculated by image thresholding in a similar manner as described in a previous work..$^{43}$ Image treatment consists in reducing the 256 grey levels from the original image to only 2 grey levels corresponding to the two phases (black for pores and grey for SDC). This is achieved by applying a threshold to the grey level histogram of the original image to obtain two binary images corresponding to the SDC and pore phases.

\subsection{Processing variations}

In order to optimize the microstructure for the electrochemical and mechanical behaviour, several design parameters were modified during processing of the tubular supports. The three 
key design parameters of these supports are as: content of 10 $\mathrm{wt} \%$ sucrose as a pore former, sintering temperature of $1450{ }^{\circ} \mathrm{C}$ (then reduced at $700{ }^{\circ} \mathrm{C}$ ), and wall thickness of $380 \mu \mathrm{m}(2.4 \mathrm{~mm}$ outer diameter). These parameters will be modified by: (1) varying the percent of pore former between 0 and $15 \mathrm{wt} \%$ sucrose, (2) decreasing the sintering temperature to 1400 and $1350{ }^{\circ} \mathrm{C}$, and (3) increasing the wall thickness to $700 \mu \mathrm{m}$ for 2.4 $\mathrm{mm}$ outer diameter, $800 \mu \mathrm{m}$ and $1200 \mu \mathrm{m}$ for $4.5 \mathrm{~mm}$ outer diameter.

\subsection{Mechanical characterization}

Three-point bending test was used to evaluate the mechanical strength of both the tubular anode supports at different processing stages (green, pre-/post-sintering, post-reduction, postredox cycle conditions) and the half-cells (anode + electrolyte) manufactured under different conditions. Flexural strength, also well-known as modulus of rupture (MOR), was determined using an uniaxial dynamic test equipment (INSTRON 8032). The samples were fixed onto the sample holder set at a span length of $30 \mathrm{~mm}$. The MOR was calculated using the following eqn (1):

$$
\operatorname{MOR}=\frac{8 F L \varnothing_{\mathrm{o}}}{\pi\left(\varnothing_{\mathrm{o}}{ }^{4}-\varnothing_{\mathrm{i}}{ }^{4}\right)}
$$

where $F$ is the measured force applied, $L$ is the span length, $\varnothing_{\mathrm{o}}$ is the outer diameter, and $\varnothing_{\mathrm{i}}$ is the inner diameter of the tested tubular supports. Mechanical strength was calculated from the collected breaking force values using the dimensions of the tubes. An average of at least 10 values was determined for each sample type.

In order to understand the reliability of the flexural strengths, their variability was analysed using the Weibull statistical method. The cumulative Weibull distribution describes the fracture probability $P$ for a given uniaxial stress $\sigma$, expressed as:

$$
P=1-\left(\exp \left(-\frac{\sigma}{\sigma_{0}}\right)^{m}\right)
$$

where $\sigma_{0}$ is a scaling parameter, referred as a characteristic strength defined as the stress at which the $P$ is $63.2 \%$, and $m$ is the Weibull modulus. ${ }^{19-21,23,44}$ The cumulative distribution function can be rewritten by taking natural logarithm for two consecutive times as:

$$
\ln \left[\ln \left(-\frac{1}{1-P}\right)\right]=m\left[\ln (\sigma)-\ln \left(\sigma_{0}\right)\right]
$$

The values of $m$ and $\sigma_{0}$ can be obtained by fitting the experimental data, using the conventional least square regression method.

\subsection{Electrochemical characterization}

The electrochemical performance of the cells was tested using $\mathrm{H}_{2}$ as fuel in the anodic compartment and air in the cathodic chamber. Electrical connections were made using four Ag wires. Ag meshes were used as current collectors at the cathode and anode (inner part of the tube). The tube was sealed using
Ceramabond 503 sealant (Aremco, US) into alumina tubes and finally all the system was introduced into a quartz tube, and sealed again to separate both chambers. Additional details of the experimental setup can be found in previous works. ${ }^{45,46}$ The cell was heated up to $700{ }^{\circ} \mathrm{C}$ in a small tubular furnace under nitrogen at the anode chamber and static air at the cathode side. At this temperature, hydrogen was introduced to reduce the anode. The full reduction takes about 2 hours and subsequently the cells were characterized. Electrochemical measurements were carried out at a temperature of $650{ }^{\circ} \mathrm{C} \cdot j-V$ (current density-voltage) measurements were performed using a VSP Potentiostat/Galvanostat (Princeton Applied Research, Oak Ridge, US) in potentiodynamic mode from OCV down to $0.35 \mathrm{~V}$ at $0.25 \mathrm{~mA} \mathrm{~s}^{-1}$.

\section{Results and discussion}

\subsection{Mechanical strength of supports and half-cells during manufacturing}

MOR and the corresponding Weibull plots for the reference tubular support and half-cell at different process stages are shown in Fig. 1. A summary of the calculated MOR values and the Weibull statistical analyses performed on the data in the form of Weibull moduli and $\sigma_{0}$ values are presented in Table 1. The $\sigma_{0}$ values are a representation of the statistical probability of failure, and so, the tubular supports and half-cells will fail in large percentages at or below the $\sigma_{0}$ value. The Weibull modulus may be used to describe the scatter of the mechanical strength in brittle (or quasi-brittle) materials. The results show that although the green tubes with AFL present a relatively low mechanical strength, they are strong enough for handling. In contrast, the tubular supports pre-sintered at $1100{ }^{\circ} \mathrm{C}$ are remarkable brittle and weak. In addition, the tubular support without AFL possesses lower mechanical strength than that with AFL, which is attributed to the effect of AFL microstructure with higher density compared to the support. In both cases, the large scatter is attributed to a lack of uniformity in this step of the fabrication process. As expected, the co-sintering process of the half-cell (tubular support and electrolyte) at $1450{ }^{\circ} \mathrm{C}$ significantly increases their mechanical strength. However, the MOR value of tubular support is more strongly increased after sintering the support without electrolyte. This decrease in the MOR value may be due to the thermo-mechanical stress generated by electrolyte layer on the support. Finally, the reduction process of $\mathrm{NiO}$ to $\mathrm{Ni}$ improves the mechanical strength and Weibull modulus of the half-cell, due to the high toughness of Ni-SDC cermet skeleton in the tubular support of half-cell. The MOR value in the reduced support of half-cell is around $20-30 \%$ lower than those reported in previous studies for Ni-YSZ/YSZ tubular half-cells also tested by three- or fourpoint bending. ${ }^{20,21}$ This decrease can be attributed to both the microstructural differences of tubular support and the use of doped ceria in the support, AFL and electrolyte, which presents lower mechanical properties than YSZ. ${ }^{47,48}$ In any case, the mechanical strength in terms of MOR and Weibull modulus for the studied half-cell may be suitable for their implementation in robust stacks., ${ }^{5,21}$ 


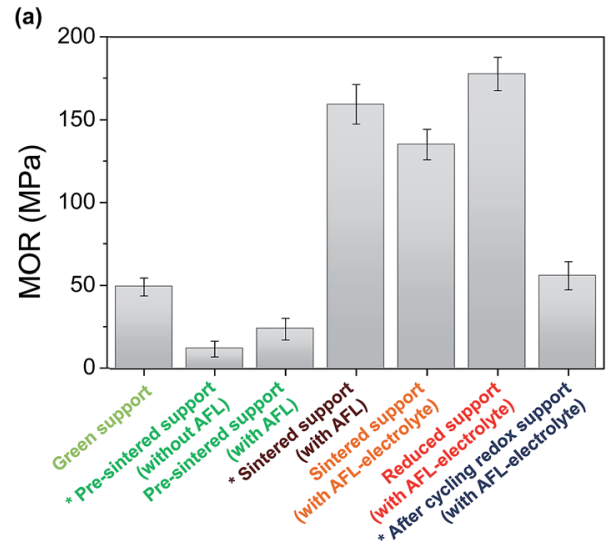

(b)

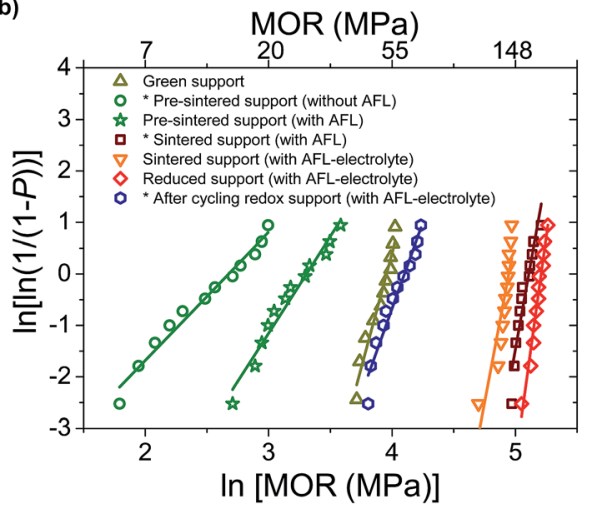

Fig. 1 (a) MOR values and (b) Weibull plots of MOR for the reference tubular support at different processing stages. Note: $(*)$ indicates the stages do not present in the standard conditions of processing and/or operation.

Table 1 Summary of MOR values, and the mean strength and modulus from Weibull analysis for the reference tubular support at different processing stages. Note: $(*)$ indicates the stages do not present in the standard conditions of processing and/or operation

\begin{tabular}{lccc}
\hline & & \multicolumn{2}{l}{$\begin{array}{l}\text { Weibull } \\
\text { parameters }\end{array}$} \\
\cline { 3 - 4 } $\begin{array}{l}\text { Processing stages of } \\
\text { reference half-cell }\end{array}$ & MOR (MPa) & $\sigma_{0}$ & $m$ \\
\hline $\begin{array}{l}\text { Green support } \\
\begin{array}{l}\text { Pre-sintered support } \\
\text { (without AFL)* }\end{array}\end{array}$ & $49.4 \pm 5.4$ & 52.2 & 8.9 \\
$\begin{array}{l}\text { Pre-sintered support } \\
\text { (with AFL) }\end{array}$ & $11.9 \pm 4.8$ & 14.5 & 2.5 \\
$\begin{array}{l}\text { Sintered support } \\
\text { (with AFL)* }\end{array}$ & $23.9 \pm 6.6$ & 27.4 & 3.8 \\
$\begin{array}{l}\text { Sintered support } \\
\text { (with AFL-electrolyte) }\end{array}$ & $159.4 \pm 11.8$ & 165.8 & 13.4 \\
$\begin{array}{l}\text { Reduced support } \\
\text { (with AFL-electrolyte) }\end{array}$ & $135.2 \pm 9.2$ & 140.8 & 12.8 \\
$\begin{array}{l}\text { After cycling redox support } \\
\text { (with AFL-electrolyte) }\end{array}$ & $177.6 \pm 10.1$ & 182.6 & 17.5 \\
& $56.0 \pm 8.4$ & 60.3 & 6.7 \\
& & & \\
& & & \\
\end{tabular}

On the other hand, one full redox cycle: (1) reduction under $\mathrm{H}_{2}$ at $700{ }^{\circ} \mathrm{C}$ for $2 \mathrm{~h},(2)$ re-oxidation under synthetic air at $700{ }^{\circ} \mathrm{C}$ for $5 \mathrm{~h}$, and (3) post-reduction $\left(\mathrm{H}_{2} / 700{ }^{\circ} \mathrm{C} / 2 \mathrm{~h}\right)$, produces a remarkable decrease in the mechanical strength of half-cell. As observed in Fig. 2, re-oxidation and post-reduction of the support and AFL may origin irreversible damages to the tubular half-cell: fractures in the microstructural integrity of the support, AFL and electrolyte, as well as delamination between the different components. This is attributed to the increase of volume during nickel oxidation, which induces high tensile stress and cracks at interfaces. ${ }^{49,50}$

\subsection{Mechanical properties of the microtubular cells}

3.2.1 Porosity. The first studied processing variable is the amount of pore former used for the tubular supports. The different microstructures of supports for the studied cells are shown in the SEM micrographs of Fig. 3a-d. Pores (black contrast) can be observed in two different morphologies. Ones with sizes of several micrometers (macroporous) and sphericallike form mainly created by the pore former, whereas the others (sub-microporous) are conforming an interconnected pore network generated during NiO reduction. The walls of both pore morphologies are homogeneously packed with both Ni (light grey contrast) and GDC (white contrast) phases. As the porosity amount and pore size distribution is critical for a suitable anode performance and mechanical strength in tubular SOFCs, mercury porosimetry tests were performed. Fig. 3e shows the pore size distributions for the supports with different amounts of pore former (between 0 and $15 \mathrm{wt} \%$ ). The difference in porosity amount and pore size distribution is originated from the amount of pore former added in each formulation of aqueous slurry. Both the pore size distribution and the microstructure observed in the support without pore former mainly show sub-microporosity of $\mathrm{NiO}$ reduction, and relatively small amounts of microporous probably created by removing water and additives (agarose and dispersant) during the sintering process. In the other supports, both the macroporosity fraction and the porous size is increased with the amount of added pore former, which may be related with the tendency to the agglomeration of the pore former in the aqueous slurry.

Afterwards, the mechanical strength of the different supports was evaluated. As shown in Fig. 4 and Table 2, an almost linear relationship between the increase of pore former (in weight, wt $\%$ ) and the decrease of MOR is observed for the studies pore former range (between 0 and $15 \mathrm{wt} \%$ ). For example, a $5 \mathrm{wt} \%$ increase in pore former with respect to the reference support (10 wt $\%$ ) decreases the strength from 177.6 $\pm 10.1 \mathrm{MPa}$ to $102.2 \pm 21.4 \mathrm{MPa}$, which is approximately a decrease of $42 \%$. Furthermore, the mechanical integrity of these supports with 15 $\mathrm{wt} \%$ pore former is relatively critical during the manufacturing process, as a consequence of their high porosity after presintering. According to their Weibull modulus, these conditions yield high failure percentages during fabrication, making it difficult to obtain suitable cells for electrochemical testing. As a consequence, the support with $15 \mathrm{wt} \%$ pore former and $62 \%$ porosity was finally dismissed, and unfortunately, it could not be electrochemically tested, due to its low mechanical strength and low dimensional stability. In contrast, a decrease of pore former to $5 \mathrm{wt} \%$ and $0 \mathrm{wt} \%$ increases the mechanical strength 

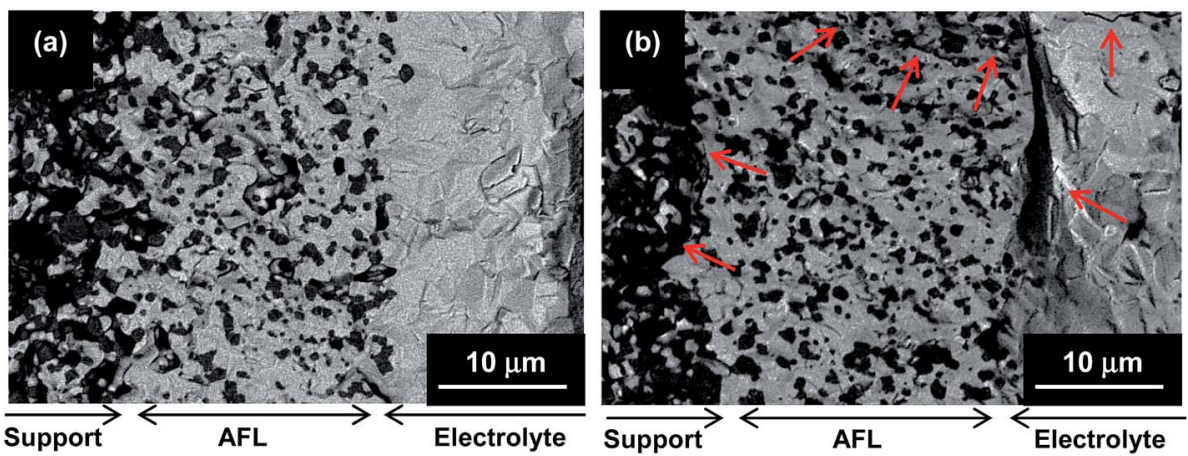

Fig. 2 SEM images of: (a) half-cell after the reduction process, and (b) reduced half-cell after one redox cycle. The arrows indicate different cracks at the region of support, AFL and electrolyte.

to $212.8 \pm 12.2 \mathrm{MPa}$ and $229.1 \pm 10.5 \mathrm{MPa}$, respectively (improvement of $20 \%$ and $23 \%$ vs. to the reference support). In conclusion, the large variation in porosity and pore size distribution between the half-cell supports with different amounts of pore former would explain the apparent difference in mechanical strength.

3.2.2 Sintering temperature. The effect of the sintering temperature was also studied in the range of $1350{ }^{\circ} \mathrm{C}$ to $1450{ }^{\circ} \mathrm{C}$. MOR values were measured for samples sintered at $1350{ }^{\circ} \mathrm{C}$, $1400{ }^{\circ} \mathrm{C}$ and $1450{ }^{\circ} \mathrm{C}$, obtaining $95.9 \pm 19.9 \mathrm{MPa}, 147.7 \pm$ 15.8 MPa and 177.6 \pm 10.1 MPa, respectively (Fig. 5 and Table 2). According to previous works, ${ }^{\mathbf{1 6}, 19,51}$ an increase in the sintering temperature causes the shrinkage of pores, thus diminishing the porosity of the support. As shown in Fig. 5a, the decrease of sintering temperature to $1400{ }^{\circ} \mathrm{C}$ and $1350{ }^{\circ} \mathrm{C}$ generates an increase of the support porosity to $56 \%$ and $61 \%$,

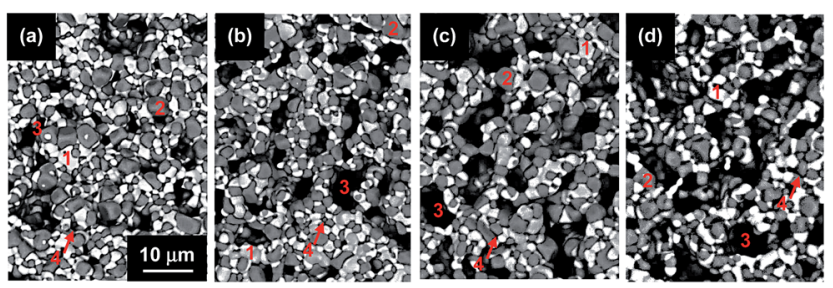

(e)

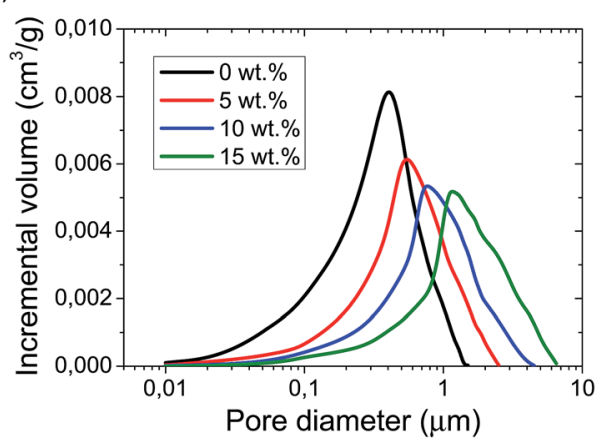

Fig. 3 SEM micrographs showing the microstructures of the reduced supports with different amounts of sucrose added as a pore former: (a) $0 \mathrm{wt} \%$, (b) $5 \mathrm{wt} \%$, (c) $10 \mathrm{wt} \%$, (d) $15 \mathrm{wt} \%$; and (e) the corresponding pore size distributions for the different amounts of pore former. Note: numbers in $(a-d)$ correspond to regions of GDC (1), Ni (2), macropores (3) and sub-micropores (4). and also a decrease of the relative density of electrolyte layer to $94 \%$ and $91 \%$, respectively. From the results obtained by variations in pore former discussed above section, the increased porosity ( $\sim 10 \%)$ caused by a lower sintering temperature (1350 ${ }^{\circ} \mathrm{C}$ ) lead to a decrease in mechanical strength of $46 \%$, which is in agreement with the three-point bending tests. Therefore, the mechanical strength in the range between $1350{ }^{\circ} \mathrm{C}$ and $1450{ }^{\circ} \mathrm{C}$ is directly related to the porosity attributed to the shrinkage of the pores. As the sintering temperature (1350-1450 ${ }^{\circ} \mathrm{C}$ ) of halfcells has a moderate impact on the mechanical strength, the optimal temperatures for both pre-sintering of tubular support and co-sintering of half-cell (support with electrolyte) must be correlated to their difference in shrinkage. For this reason, it
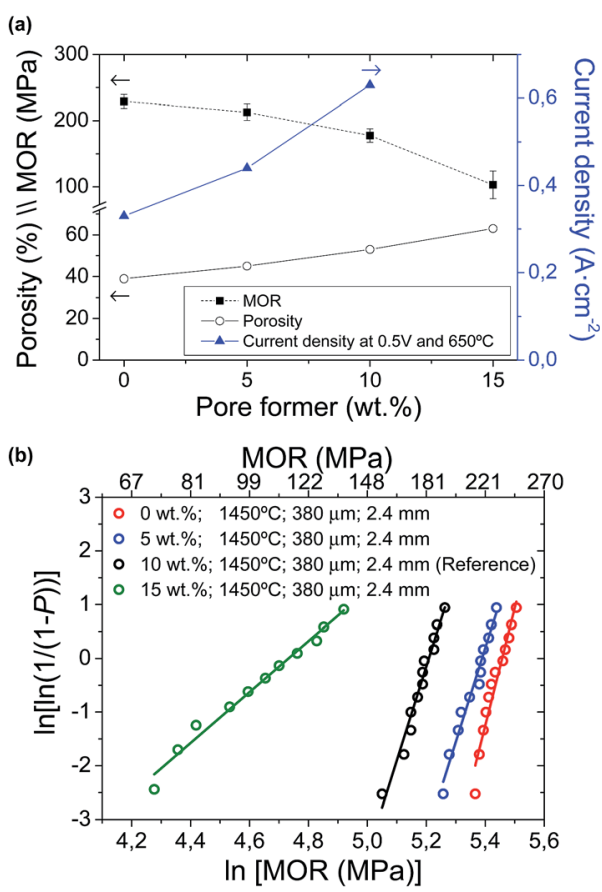

Fig. 4 (a) MOR of half-cells (support-AFL-electrolyte), porosity of reduced support, and current density of cell (at $0.5 \mathrm{~V}$ and $650{ }^{\circ} \mathrm{C}$ ) as a function of the amount of pore former (sucrose). (b) Weibull plots of MOR for half-cells with the reduced supports and different amount of pore formers. 
Table 2 Summary of MOR values (ranked in decreasing order), and the mean strength and modulus from Weibull analysis for the half-cells with different variations of processing in the tubular supports: pore former, sintering temperature, wall thickness and outer diameter. Note: numbers indicate that the cells could be electrochemically tested: (1) without any problem, (2) with significant gas leakage, and (3) with significant gas leakage and/or insufficient mechanical strength

\begin{tabular}{|c|c|c|c|}
\hline \multirow{2}{*}{$\begin{array}{l}\text { Half-cells with different } \\
\text { processing variations }\end{array}$} & \multirow[b]{2}{*}{ MOR (MPa) } & \multicolumn{2}{|c|}{$\begin{array}{l}\text { Weibull } \\
\text { parameters }\end{array}$} \\
\hline & & $\sigma_{0}$ & $m$ \\
\hline $0 \mathrm{wt} \% ; 1450{ }^{\circ} \mathrm{C} ; 380 \mu \mathrm{m} ; 2.4 \mathrm{~mm}(1)$ & $229.1 \pm 10.5$ & 233.2 & 21.9 \\
\hline $5 \mathrm{wt} \% ; 1450{ }^{\circ} \mathrm{C} ; 380 \mu \mathrm{m} ; 2.4 \mathrm{~mm}(1)$ & $212.8 \pm 11.2$ & 219.2 & 18.5 \\
\hline $10 \mathrm{wt} \% ; 1450{ }^{\circ} \mathrm{C} ; 1200 \mu \mathrm{m} ; 4.5 \mathrm{~mm}(1)$ & $185.1 \pm 9.4$ & 190.0 & 19.8 \\
\hline $10 \mathrm{wt} \% ; 1450{ }^{\circ} \mathrm{C} ; 700 \mu \mathrm{m} ; 2.4 \mathrm{~mm}(1)$ & $183.5 \pm 10.9$ & 189.3 & 16.8 \\
\hline $\begin{array}{l}10 \mathrm{wt} \% ; 1450^{\circ} \mathrm{C} ; 380 \mu \mathrm{m} ; 2.4 \mathrm{~mm} \\
\text { (reference) (1) }\end{array}$ & $177.6 \pm 10.1$ & 182.6 & 17.5 \\
\hline $10 \mathrm{wt} \% ; 1450^{\circ} \mathrm{C} ; 800 \mu \mathrm{m} ; 4.5 \mathrm{~mm}(2)$ & $173.5 \pm 12.2$ & 179.0 & 14.3 \\
\hline $10 \mathrm{wt} \% ; 1400{ }^{\circ} \mathrm{C} ; 380 \mu \mathrm{m} ; 2.4 \mathrm{~mm}(2)$ & $147.7 \pm 15.8$ & 156.0 & 9.4 \\
\hline $15 \mathrm{wt} \% ; 1450{ }^{\circ} \mathrm{C} ; 380 \mu \mathrm{m} ; 2.4 \mathrm{~mm}(3)$ & $102.2 \pm 21.4$ & 113.8 & 4.7 \\
\hline $10 \mathrm{wt} \% ; 1350{ }^{\circ} \mathrm{C} ; 380 \mu \mathrm{m} ; 2.4 \mathrm{~mm}(3)$ & $95.9 \pm 19.9$ & 106.7 & 4.9 \\
\hline
\end{tabular}
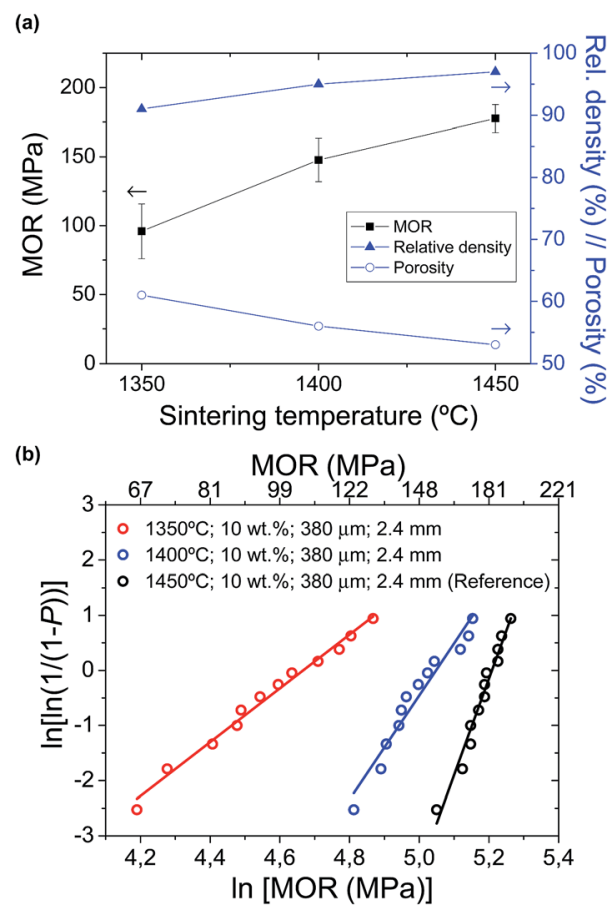

Fig. 5 (a) MOR of half-cells, relative density of electrolyte layer and porosity of support as a function of sintering temperature, using 10 wt\% sucrose as a pore former. (b) Weibull plots of MOR for the halfcells with the reduced supports and sintered at different temperatures.

should be also taken into account that a reduction of the cosintering temperature also requires a decrease in the presintering one, incrementing the probability of mechanical failure during manufacturing. Therefore, both $1100{ }^{\circ} \mathrm{C}$ presintering and $1450{ }^{\circ} \mathrm{C}$ co-sintering were selected as the best combination of temperatures in order to minimize any break during manufacturing and finally guarantee a dense electrolyte and a good adhesion of support-AFL-electrolyte.

3.2.3 Wall thickness and outer diameter. Finally, the effect of the wall thickness and outer diameter of the tubular supports were also studied for several half-cell configurations, as shown in Fig. 6. As observed, the wall thickness was increased from 380 $\mu \mathrm{m}$ (for the reference half-cell) to $700 \mu \mathrm{m}$ for $2.4 \mathrm{~mm}$ outer diameter, $800 \mu \mathrm{m}$ and $1200 \mu \mathrm{m}$ for $4.5 \mathrm{~mm}$ outer diameter. In the same way, the outer diameter was also increased from 2.4 $\mathrm{mm}$ (for the half-cell with $700 \mu \mathrm{m}$ wall thickness) to $4.5 \mathrm{~mm}$ outer diameter (for $800 \mu \mathrm{m}$ wall thickness). In Fig. 7 and Table 2 , it can be observed that MOR and Weibull values are not strongly affected by the variation of the wall thickness and outer diameter, indicating that the microstructural properties of supports are rather similar. Actually, porosity measurements after the reduction process for the different cells confirmed that all supports present similar values $(53,52,53$ and $54 \%$ for 380 , 700,800 and $1200 \mu \mathrm{m}$ wall thickness). It is then concluded that MOR values are independent of the dimensions of the tube, as the expression for its calculation presents a tube geometric factor $\left[8 \varnothing_{\mathrm{o}} / \pi\left(\varnothing_{\mathrm{o}}{ }^{4}-\varnothing_{\mathrm{i}}{ }^{4}\right)\right]$ that normalizes the different dimensions of tubes taking into account the outer $\left(\varnothing_{\mathrm{o}}\right)$ and inner $\left(\varnothing_{\mathrm{i}}\right)$ diameters. Since the support porosity and the span length are equivalent in the mechanically tested half-cells, their differences in applied force to rupture are only attributed to the variation in wall thickness and outer diameter. As shown in Fig. 7a, an increase of wall thickness and/or outer diameter reduces the tube geometric factor, and consequently increases the force to rupture up to 8 times (for the half-cell of $1200 \mu \mathrm{m}$ wall thickness and $4.5 \mathrm{~mm}$ outer diameter) with respect to the reference half-cell. In addition, the influence of the geometric factor is more remarkable when increasing the outer diameter (from $2.4 \mathrm{~mm}$ to $4.5 \mathrm{~mm}$ ) than that of the wall thickness (from 380 to $700 \mu \mathrm{m}$ for $2.4 \mathrm{~mm}$ outer diameter, and also from 800 to $1200 \mu \mathrm{m}$ for $4.5 \mathrm{~mm}$ outer diameter). In conclusion, it is quite important to take into account that a decrease of wall thickness and/or outer diameter increments the tube geometric factor, thus reducing strongly the applied force to rupture at a constant span length, and vice versa, decreasing the span length at a determined force to rupture.

\subsection{Electrochemical characterization}

A detailed electrochemical characterization of this type of cells was already reported in a previous work. ${ }^{40}$ Current densities at $0.5 \mathrm{~V}$ and $650{ }^{\circ} \mathrm{C}$ for the cells with different amounts of pore former in the support are also presented in Fig. 3a. As clearly observed, current density values are significantly enhanced when increasing the amount of pore former in the support (0.33, 0.44 and $0.63 \mathrm{~A} \mathrm{~cm}^{-2}$ with 0,5 and $10 \mathrm{wt} \%$ pore former, respectively). Unfortunately, the cell with $15 \mathrm{wt} \%$ pore former in the support could not be electrochemically tested properly, due to its low mechanical strength and low dimensional stability. The current density, as an electrochemical parameter, clearly shows the gas transport limitations on cell performances, especially working at high current densities. The effect of gas transport limitation was confirmed by EIS experiments, ${ }^{\mathbf{4 0}}$ where 

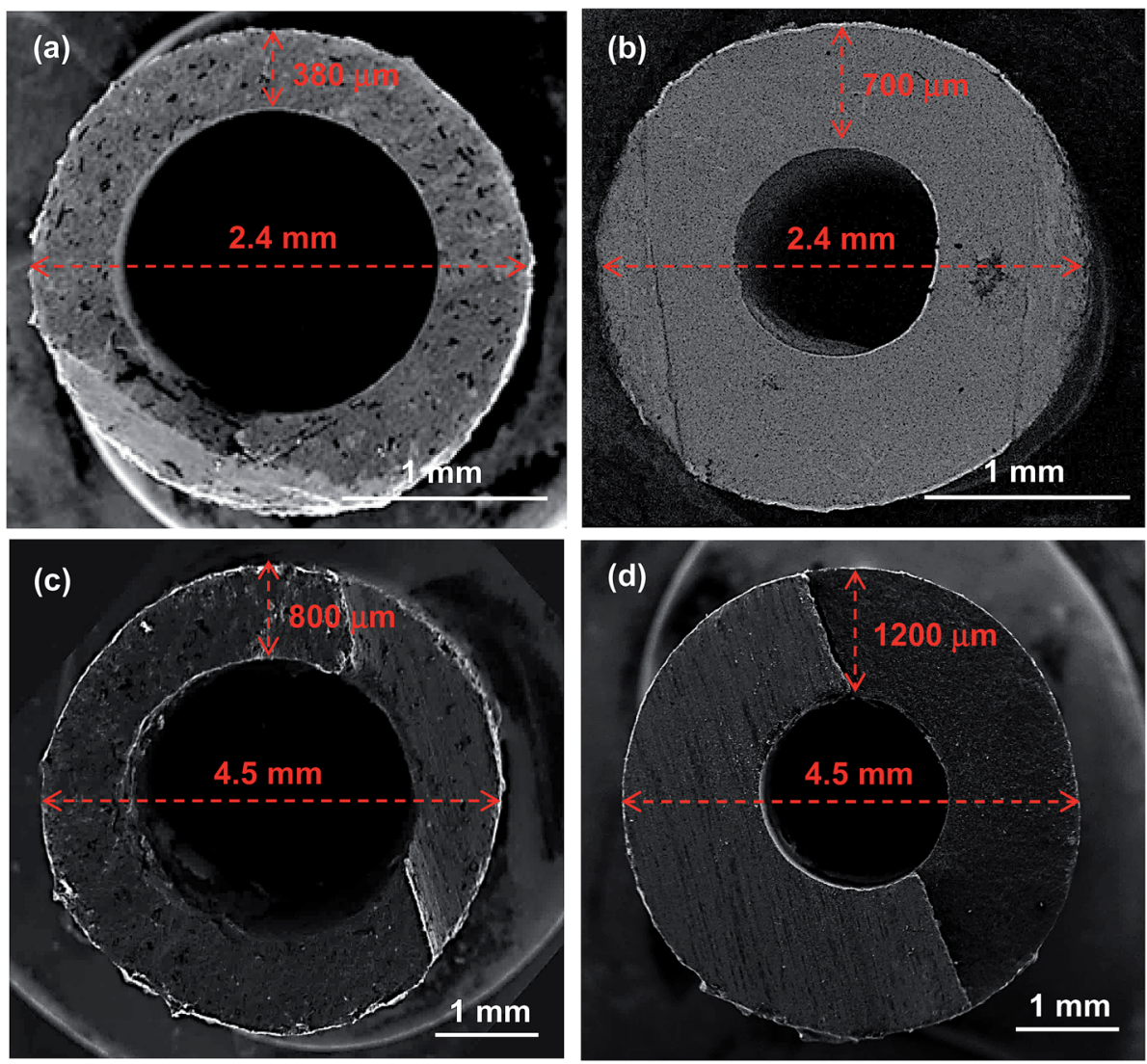

Fig. 6 Half-cell configurations with different tubular support dimensions in wall thickness and outer diameter: (a) $380 \mu \mathrm{m}$ and $2.4 \mathrm{~mm}$ (reference half-cell), (b) $700 \mu \mathrm{m}$ and $2.4 \mathrm{~mm}$, (c) $800 \mu \mathrm{m}$ and $4.5 \mathrm{~mm}$, and (d) $1200 \mu \mathrm{m}$ and $4.5 \mathrm{~mm}$, respectively.

the low frequency Warburg response (hydrogen transport through the Ni-SDC support) increases when reducing the porosity of the support. Therefore, the large variation in porosity and pore size distribution between the cells with different amounts of pore former in the support would explain the significant differences in cell performance. As a summary, although the addition of pore former produces a remarkable mechanical weakness in the cells, but it also leads to an improvement on cell performance. The sample with about 50\% porosity in the support was found to be the optimal to avoid a strong limitation of gas transport and guarantee enough mechanical strength.

On the other hand, Fig. 8 also shows the cell performances for different cells as a function of the wall thickness $(380,700$ and $1200 \mu \mathrm{m}$ ), collected at $0.5 \mathrm{~V}$ and $650{ }^{\circ} \mathrm{C}$. Unfortunately, the cell with $800 \mu \mathrm{m}$ wall thickness and $4.5 \mathrm{~mm}$ outer diameter could not be tested with a suitable electrochemical stability in operation. Although this configuration presented an enough mechanical strength and Weibull parameters close to the others, the presence of punctual microcracks and/or pores at the electrolyte layer created during the sintering process generated significant gas leakages between anode and cathode chambers. In order to obtain an enhanced electrolyte layer, it would be necessary to modify both pre-sintering and sintering temperatures. In the cells tested without remarkable problems, it is observed that both area and volumetric power densities are significantly improved with the reduction of the wall thickness. In terms of area power density, the performance of the reference cell is increased more than $150 \%$ and $200 \%\left(0.42 \mathrm{~W} \mathrm{~cm}^{-2}\right.$ with almost $400 \mu \mathrm{m}$ wall thickness) compared to the cells with 700 $\mu \mathrm{m}\left(0.24 \mathrm{~W} \mathrm{~cm}^{-2}\right)$ and $1200 \mu \mathrm{m}\left(0.18 \mathrm{~W} \mathrm{~cm}^{-2}\right)$ wall thickness, respectively. In contrast, the volumetric power density of reference cell $\left(0.70 \mathrm{~kW} \mathrm{~L}^{-1}\right.$ with $2.4 \mathrm{~mm}$ outer diameter $)$ is 4 times higher than that of $1200 \mu \mathrm{m}$ wall thickness and $4.5 \mathrm{~mm}$ outer diameter $\left(0.16 \mathrm{~kW} \mathrm{~L}^{-1}\right)$, as the volumetric performance depends on the wall thickness and additionally the inverse of the cell outer diameter. This is also consistent with EIS analysis, as concentration polarization increases when increasing wall thickness. ${ }^{40}$ In conclusion, the reduction of wall thickness and outer diameter in a mT-SOFC significantly increases the volumetric and area power density keeping almost constant both the MOR and the microstructural properties.

\section{Conclusions}

Microtubular SOFCs based on Ni-SDC support and doped ceria electrolyte fabricated by gel-casting, have been mechanically characterized in order to analyse the macro-mechanical failure behaviour during their manufacturing. Three-point bending tests evidence that the pre-sintering of tubular support at $1100{ }^{\circ} \mathrm{C}$ is the most critical step mechanically, as the MOR is 

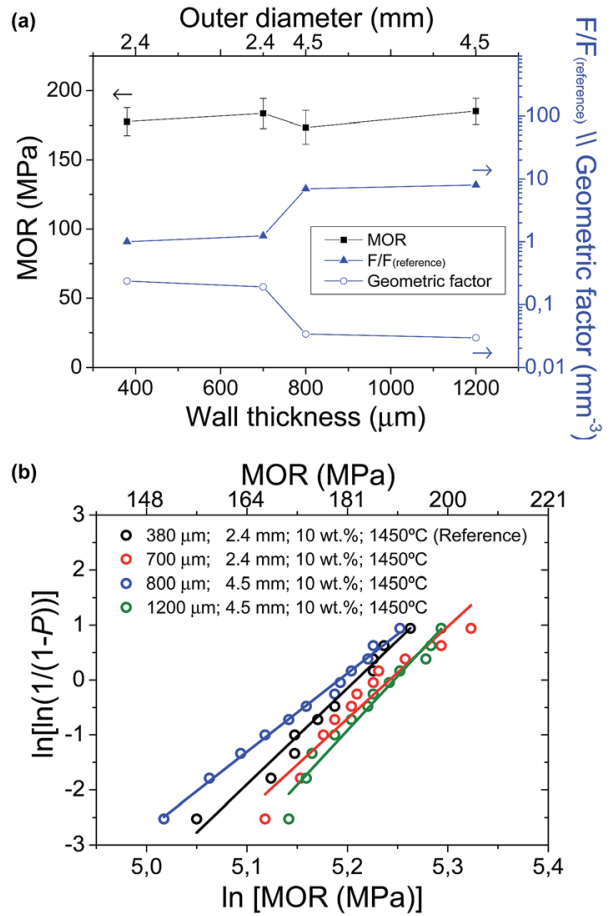

Fig. 7 (a) MOR, relation of forces to rupture with respect to the reference half-cell $\left(F / F_{(\text {reference) }}\right)$ and tubular geometric factor as a function of the wall thickness of half-cell (support-AFL-electrolyte). (b) Weibull plots of MOR from three-point bending tests of the halfcells with the reduced supports and different wall thickness and outer diameter.

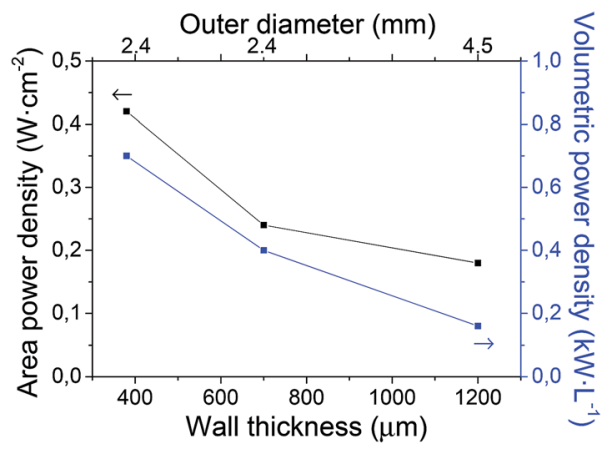

Fig. 8 Area and volumetric power densities (at $0.5 \mathrm{~V}$ and $650{ }^{\circ} \mathrm{C}$ ) as a function of the wall thickness of half-cell (support-AFL-electrolyte).

only $23.9 \pm 6.6 \mathrm{MPa}$, making difficult their handling. Afterwards, the co-sintering and reduction processes significantly improve both the MOR of the half-cell to $177.6 \pm 10.1 \mathrm{MPa}$ and the Weibull modulus ( $m=17.5$ ), evidencing that they can be suitable for their implementation in robust stacks. The low amount of scattering in the final half-cells is attributed to the good uniformity of the overall fabrication process, except for pre-sintering step.

On the other hand, the influence of Ni-SDC tubular support on the electrochemical and mechanical properties of mT-SOFCs has been evaluated by varying several processing parameters: amount of sucrose as a pore former, sintering temperature, and wall thickness and outer diameter. For this purpose, a half-cell fabricated with $10 \mathrm{wt} \%$ pore former, sintered at $1450{ }^{\circ} \mathrm{C}$, and $380 \mu \mathrm{m}$ wall thickness and $2.4 \mathrm{~mm}$ outer diameter has been used as a reference. The best results were attained with the reference cell $\left(53 \%\right.$ porosity and sintered at $\left.1450{ }^{\circ} \mathrm{C}\right)$ achieving optimized gas transport (high current densities) and good mechanical strength with low scattering. This is mainly attributed to a good microstructural support in terms of porosity amount and distribution (with $10 \mathrm{wt} \%$ pore former), but also guaranteeing a dense electrolyte and a good adhesion of support-AFL-electrolyte. Finally, it was found that the volumetric and area power densities are strongly enhanced by the reduction of wall thickness and outer diameter in a mT-SOFC. For instance, the volumetric power density of reference cell $\left(0.70 \mathrm{~kW} \mathrm{~L}{ }^{-1}\right)$ is 4 times higher than that of $1200 \mu \mathrm{m}$ wall thickness and $4.5 \mathrm{~mm}$ outer diameter $\left(0.16 \mathrm{~kW} \mathrm{~L}^{-1}\right)$. Although both design parameters of tubular support are not significantly affected on the MOR values and microstructural properties, they increment the tube geometric factor strongly decreasing the applied force to rupture at a determined span length, and vice versa. In conclusion, the tubular support design for a mT-SOFC stack requires a good balance between wall thickness, outer diameter and span length in order to maximize the volumetric and area performance and minimize the loss of mechanical strength in terms of applied force to rupture.

\section{Acknowledgements}

The present work was financed by the Spanish Government (Ministerio de Economía y Competitividad) and the Feder program of the European Union with the project MAT201568078-R.

\section{References}

1 R. M. Ormerod, Solid oxide fuel cells review, Chem. Soc. Rev., 2003, 32, 17-28.

2 P. Aguiar, D. J. L. Brett and N. P. Brandon, J. Power Sources, 2007, 171, 186-197.

3 K. Kendall and M. Palin, J. Power Sources, 1998, 71, 268-270. 4 C. E. Hatchwell, N. M. Sammes and K. Kendall, J. Power Sources, 1998, 70, 85-90.

5 V. Lawlor, S. Griesser, G. Buchinger, A. G. Olabi, S. Cordiner and D. Meissner, J. Power Sources, 2009, 193, 387-399.

6 T. Suzuki, T. Yamaguchi, Y. Fujishiro and M. Awano, J. Electrochem. Soc., 2006, 1535, A925-A928.

7 V. M. Orera, A. Larrea and M. A. Laguna-Bercero, Front. Energy Res., 2014, 2, 1-13.

8 M. Torrell, A. Morata, P. Kayser, M. Kendall, K. Kendall and A. Tarancón, J. Power Sources, 2015, 285, 439-448.

9 H. Monzón and M. A. Laguna-Bercero, Electrochim. Acta, 2016, 222, 1622-1627.

10 A. Hornés, M. Torrell, A. Morata, M. Kendall, K. Kendall and A. Tarancón, Int. J. Hydrogen Energy, 2017, 1-13.

11 B. C. H. Steele and A. Heinzel, Nature, 2001, 414, 345-352. 
12 V. V. Kharton, F. M. B. Marques and A. Atkinson, Solid State Ionics, 2004, 174, 135-149.

13 J. Fergus, R. Hui, X. Li, D. P. Wilkinson and J. Zhang, Solid Oxide Fuel Cells: Materials Properties and Performance, CRC, 2008.

14 M. Morales, J. J. Roa, J. M. Perez-Falcón, J. Tartaj, F. Espiell and M. Segarra, J. Power Sources, 2014, 246, 918-925.

15 M. Morales, J. J. Roa, J. Tartaj and M. Segarra, J. Eur. Ceram. Soc., 2016, 36, 1-16.

16 K. S. Howe, G. J. Thompson and K. Kendall, J. Power Sources, 2011, 196, 1677-1686.

17 T. Suzuki, Z. Hasan, Y. Funahashi, T. Yamaguchi, Y. Fujishiro and M. Awano, Science, 2009, 325(5942), 852855.

18 C. Jin, J. Liu, L. Li and Y. Bai, J. Membr. Sci., 2009, 341, 233237.

19 B. R. Roy, N. M. Sammes, T. Suzuki, Y. Funahashi and M. Awano, J. Power Sources, 2009, 188, 220-224.

20 N. M. Sammes and Y. Du, J. Mater. Sci., 2003, 38, 4811-4816.

21 N. M. Sammes and Y. Du, Int. J. Appl. Ceram. Technol., 2007, 4, 89-102.

22 N. Droushiotis, U. Doraswami, K. Kanawka, G. H. Kelsall and K. Li, Solid State Ionics, 2009, 180, 1091-1099.

23 Y.-W. Sin, K. Galloway, B. Roy, N. M. Sammes, J.-H. Song, T. Suzuki and M. Awano, Int. J. Hydrogen Energy, 2011, 36, 1882-1889.

24 H. Sumi, T. Yamaguchi, K. Hamamoto, T. Suzuki and Y. Fujishiro, J. Am. Ceram. Soc., 2013, 96, 3584-3588.

25 Y. Du, N. M. Sammes, G. A. Tompsett, D. Zhang, J. Swan and M. Bowdend, J. Electrochem. Soc., 2003, 150, A74-A78.

26 V. Gil, J. Gurauskis, R. Campana, R. I. Merino, A. Larrea and V. M. Orera, J. Power Sources, 2011, 196, 1184.

27 T. Mahata, S. R. Nair, R. K. Lenka and P. K. Sinha, Int. J. Hydrogen Energy, 2012, 37, 3874.

28 A. Mirahmadi and K. Valefi, Ionics, 2011, 17, 767.

29 J. J. Roa, J. C. Ruiz-Morales, J. Canales-Vázquez, M. Morales, X. G. Capdevila, P. Núñez and M. Segarra, Fuel Cells, 2011, 11, 124-130.

30 H. Monzón, M. A. Laguna-Bercero, A. Larrea, B. I. Arias, A. Várez and B. Levenfeld, Int. J. Hydrogen Energy, 2014, 39, 5470 .
31 B. I. Arias-Serrano, M. E. Sotomayor, A. Várez, B. Levenfeld, H. Monzón, M. A. Laguna-Bercero and A. Larrea, RSC Adv., 2016, 6, 19007-19015.

32 J. S. Cherng, C. C. Wu, W. H. Chen and T. H. Yeh, Ceram. Int., 2013, 39, S601.

33 M. H. D. Othman, N. Droushiotis, Z. Wu, G. Kelsall and K. Li, Adv. Mater., 2011, 23, 2480.

34 A. Douy, Int. J. Inorg. Mater., 2001, 3, 699-707.

35 A. J. Millán, I. Santacruz, A. J. Sánchez-Herencia, M. I. Nieto and R. Moreno, Adv. Eng. Mater., 2002, 4, 913-915.

36 K. Prabhakaran, A. Melkeri, M. O. Beigh, N. M. Gokhale and S. C. Sharma, J. Am. Ceram. Soc., 2007, 90(2), 622-625.

37 J. Yang, J. Yu and Y. Huang, J. Eur. Ceram. Soc., 2011, 31, 2569-2591.

38 M. E. Navarro, X. G. Capdevila, M. Morales, J. J. Roa and M. Segarra, J. Power Sources, 2012, 200, 45-52.

39 M. Morales, M. E. Navarro, X. G. Capdevila, J. J. Roa and M. Segarra, Ceram. Int., 2012, 38, 3713.

40 M. Morales, M. A. Laguna-Bercero, M. E. Navarro, F. Espiell and M. Segarra, RSC Adv., 2015, 5, 39350-39357.

41 M. Morales, J. J. Roa, X. G. Capdevila, M. Segarra and S. Piñol, Fuel Cells, 2011, 11, 108-115.

42 M. Morales, F. Espiell and M. Segarra, J. Power Sources, 2015, 293, 366-372.

43 A. Faes, A. Hessler-Wyser, D. Presvytes, C. G. Vayenas and J. Van Herle, Fuel Cells, 2009, 9, 841-851.

44 W. Weibull, J. Appl. Math. Mech., 1951, 18, 293-297.

45 M. Á. Laguna-Bercero, A. Férriz, A. Larrea, L. Correas and V. M. Orera, Fuel Cells, 2013, 13, 1116-1122.

46 M. A. Laguna-Bercero, R. Campana, A. Larrea, J. A. Kilner and V. M. Orera, J. Electrochem. Soc., 2010, 157, B852-B855.

47 M. Morales, J. J. Roa, X. G. Capdevila, M. Segarra and S. Piñol, J. New Mater. Electrochem. Syst., 2009, 12, 187-193.

48 M. Morales, J. J. Roa, X. G. Capdevila, M. Segarra and S. Piñol, Acta Mater., 2010, 58(7), 2504-2509.

49 H. Monzón and M. A. Laguna-Bercero, Int. J. Hydrogen Energy, 2012, 37, 7262-7270.

50 A. Faes, A. Hessler-Wyser, A. Zryd and J. Van Herle, Membranes, 2012, 2, 585-664.

51 T. Suzuki, Y. Funahashi, T. Yamaguchi, Y. Fujishiro and M. Awano, J. Power Sources, 2008, 183, 544-550. 